\title{
Occurrence of Biogenic Amines in Different Types of Marketed Cheese in Gharbia Governorate
}

\author{
Nesreen Z. Eleiwa ${ }^{1}$, Hanan M. Lamada ${ }^{1}$, Marionette Z. Nassif $^{2}$ \\ ${ }^{I}$ Animal Health Research Institute, Tanta Lab and ${ }^{2}$ Animal Health Research Institute, Benha Lab.
}

\begin{abstract}
This work was applied on sixty cheese samples represented by Kareish, cheddar and Romano cheeses (20 of each). The samples were submitted to High Performance Liquid Chromatography (HPLC) for qualitative and quantitative determination of biogenic amines.The results were summarized as Kareish cheese has higher concentrations of Tyramine and Cadaverine in low and high levels of manufacturing quality ( $29.64 \pm 1.72$ and $9.91 \pm 0.60 \mathrm{mg} / \mathbf{1 0 0 g m})$ and $(17.48 \pm 1.09$ and $5.61 \pm 0.37 \mathrm{mg} / \mathbf{1 0 0 g m})$ respectively, Meanwhile, Histamine level was higher in both levels of Romano cheese $(22.96 \pm 1.17$ and $18.35 \pm 1.12 \mathrm{mg} / 100 \mathrm{gm})$ respectively. Putrescine represented in high levels in cheddar cheese $(13.40 \pm 1.02$ and $10.61 \pm 0.74 \mathbf{m g} / 100 \mathrm{gm})$ respectively. Comparing with the Egyptian Organization for Standardization"EOS" (1996), all the cheese samples were not exceeded the permissible level of Cadaverine in contrast with the other biogenic amines. The study concluded that presence of high concentrations of biogenic amines reflect the bad hygienic conditions under which they produced and stored
\end{abstract}

Biogenic amines are organic, basic nitrogenous compounds with biological activity mainly formed by the decarboxylation of amino acids (Linares et al., 2011). Food -fermenting lactic acid bacteria (LAB) are generally considered to be non-toxic and non pathogenic .Some species of $\mathrm{LAB}$, however, can produce biogenic amines (Spano et al., 2010). Poly amines are classically known by their names of putrescine, spermine and spermidine. They are synthesized endogenously from ornithine and are interconvertible.In addition, an exogenous supply of polyamines is provided by dietary intake and intestinal absorption from the products of bacterial metabolism (Larque et al., 2007). Histamine is common in foods that have been aged or fermented. Cheese, yeast extracts, and tuna fish are known to have caused scombroid or histamine poisoning (Lembke, 1978). The toxic dose of biogenic amines is variable, depending on the individual's efficiency of detoxification by conversion to an aldehyde via monoamine oxidase (Edwards and Sandine, 1981). Monoamine oxidase inhibitor (MAOI) have facilitated absorption of both tyramine and histamine from the intestine and potentiated their action. Cheeses represent an ideal environment for amine production by bacterial decarboxylation of appropriate amino acids (Rice et al., 1976). In fact, during cheese ripening, degradation of casein occurs leading to accumulation of free amino acids that can be converted into biogenic amines by the activity of bacterial decarboxylases (Halasz et al.,
1994).There are many kinds of cheese produced in the world, and biogenic amines content of the cheese may be affected by many factors, as the level of free amino acids, bacterial contamination , $\mathrm{pH}$, salt concentration, storage temperature, water activity and ripening time (Stratton et al., 1992; Vale and Gloria,1997; Pinho et al., 2001). Thus, each type of cheese has its own characteristic amine profile as a result of different conditions (Polo et al., 1985). Biogenic amines can be found in high concentrations in various types of cheese, especially near the tind and in well - ripened cheese. However, amounts causing intoxication can be found only in cheese that has undergone excessive proteolysis such as Cheddar and Swiss cheese. High histamine and / or tyramine concentrations do often coincide with high concentrations of putrescine and cadaverine (Maijala and Eerola, 2002). The interest in amine determination is due to their ability to have a direct or indirect effect on human vascular and nervous systems. Indeed, a large amount of the biogenic amines such as histamine ( histamine intoxication ) and tyramine ( cheese syndrome) can cause rash, headache, nausea, hypo-or hypertension, cardiac palpitation, intracerebral haemorrhage, and anaphylactic shock , especially if alcohols or monoamine oxidase inhibitor drugs (MAOI) are ingested at the same time ( Lange et al., 2002; Vinci and Antonelli, 2002). These reactions can be potentiated by other biogenic amines, such as putrescine, cadaverine, spermine and spermidine ( Stratton 
et al., 1991).Furthermore, diamines (putrescine and cadaverine) can react with nitrate to form carcinogenic nitrosamines (Oliveira et al., 1995). Several analytical techniques including capillary electrophoresis, thin- layer chromatography,gas chromatography,ion exchange chromatography and high performance liquid chromatography (HPLC) (Mah et al., 2002; Novella-Rodrguiez et al., 2003) have been proposed for the determination of biogenic amines in various foods. Among the cited techniques, HPLC is considered the most suitable one.

So the aim of this study is the qualitative and quantitative determination of biogenic amines in different types of manufactured cheeses by using HPLC technique.

\section{Material and methods}

1. Collection of samples. Samples of Kareish, Cheddar and Romano cheese (20 of each ) were collected randomly from different supermarkets and retail stores in Gharbia Governorate and classified into low and high manufactured quality level (10 of each ). Collected samples were transferred to the Central laboratory in the faculty of veterinary medicine, Benha university with minimum of delay to be subjected to determination of biogenic amines by using High Performance Liquid Chromatography (HPLC) according to Moret and Conte (1996):

2. Extraction of Amines and Amino Acids. $125 \mathrm{~g}$ of homogenized cheese samples mixed with $125 \mathrm{ml}$ of $5 \%$ trichloroacetic acid (TCA) for 3 minutes using a warning blender, and then filteration was achieved using filter paper Whatman(No1).Moreover, $10 \mathrm{ml}$ of the extract was transferred into a suitable culture tube with $4 \mathrm{~g} \mathrm{Nacl}$ and $1 \mathrm{ml}$ of $50 \% \mathrm{NaOH}$, then shacked and extracted 3 times by $5 \mathrm{ml} \mathrm{n}$ - butanol chloform (1: $1 \mathrm{v} / \mathrm{v})$, stoppered and shacked vigorously for 2 min., followed by centrifugation for 5 min.at 3000rpm and the upper layer wastransferred to $50 \mathrm{ml}$ separating funnel using disposable pasture pipette.To combine organic extract ( upper layer ), $15 \mathrm{ml}$ of $\mathrm{n}$-hepatanes was added and extracted 3 times with $1.0 \mathrm{ml}$ portion of 0.2 NHCL layer was collected in glass stopper tube. Solution was evaporated just to dryness using water bath at 95 ${ }^{0} \mathrm{C}$ with air of air currents.

3. Derivatives of formation (Dansyl amines). $200 \mathrm{ml}$ of each stock standard solution (or sample extract) were transferred to a culture tube and dried under vacuum. About $0.5 \mathrm{ml}$ of saturated $\mathrm{NaHCO}$ solution was added to the residues of the sample extract (or the
standard).The tube stoppered and carefully mixed to prevent loss due to spattering. Carefully, $1.0 \mathrm{ml}$ dansyl chloride solution was added and mixed thoroughly using Vortex mixer. The mixture was kept in a water bath at $70^{\circ} \mathrm{C}$ for 10 min.then, the extraction of dansylated biogenic amines was carried out using 3 times of $5.0 \mathrm{ml}$ portions of diethyl -ether, and the ether layers were collected in a culture tube using disposable pasture pipette. The combined ether extracts werecarefully evaporated at $35^{\circ} \mathrm{C}$ in dry film and dissolved in $1 \mathrm{ml}$ methanol, then 10 micro liters injected in HPLC (Ordonez et al., 1997)

4. Interpretation of HPLC (Moret and Conte, 1996). The most common technique for amine analysis is HPLC using derivatization before detection. Accordingly, 5- dimethylamine- 1naphalene sulphonyl chloride was used as derivatization reagent which characterized by the reaction with both primary and secondary amine groups. The chromatographic separation was carried out to separate the three dansyl amines .Furthermore, 10,20,30,40, and50, microliter of dansyl amine standard as well as 10 micro liter of each dansyl sample extract were used. However, the chromatogram was examined under long wave of ultra violet $(254 \mathrm{~nm})$ to establish weather or not the asyl amines of interest are present in the examined sample.

Finally, the concentration of each biogenic amine in the samples was recorded as $\mathrm{mg} / 10 \mathrm{~g}$ according to the following formula:

Amine concentration $(\mathrm{mg} / 100 \mathrm{~g})=\mathrm{CV} / \mathrm{V}$ Where, $\mathrm{C}=$ Concentration of amine standard $(\mathrm{mg} / \mathrm{g}), \mathrm{V}=$ Final dilution of sample extract $(\mathrm{ml})$ and $\mathrm{W}=$ Weight of the sample in the final extract (g).

Statistical analysis. The obtained results were statistically evaluated by using analysis of variance (ANOVA) test according to Feldman, et al., (2003).

\section{Results and discussion}

Tyramine has been proved as a cause of adverse reactions, involving headache, hypertensive crisis and interactions with antidepressive drugs, which were observed after consumption of ripening cheeses (Fonberg and Sawilska, 1995).

The obtained results in table (1) revealed that Kariesh cheese showed remarkably higher tyramine concentrations compared with pasteurized milk cheeses in both low and high quality levels $(29.64 \pm 1.72$ and $17.48 \pm 1.09$ $\mathrm{mg} / 100 \mathrm{gm})$ in kariesh cheese; $(25.37 \pm 1.49$ and 
$14.10 \pm 0.84 \mathrm{mg} / 100 \mathrm{gm})$ in cheddar cheese and $(18.51 \pm 0.02$ and $12.86 \pm 0.68 \mathrm{mg} / 100 \mathrm{gm})$ in Romano cheese, respectively. Nearly similar results were recorded by Jarisch (2004). In contrast, lower concentrations of tyramine were reported by Dardir and Abeer (2007); Ekbal and Amr (2010).

Owing to their microbial origin, biogenic amines can be formed by microbial contamination. In this sense, Rodriguez et al., 2004) reported that raw milk cheese had higher level of biogenic amines as compared with pasteurized milk cheese due to its higher microbial contamination particularly with Enterobacteriaceae and Enterococci. Moreover biogenic amines in food are used as indicator of the hygienic quality of raw materials employed in food manufacture as well as the hygienic quality during food processing (Jover et al., 1997; Schneller et al., 1997)

Histamine poisoning is a chemical intoxication following the ingestion of foods that contain high levels of histamine. The incubation period is very short ( few minutes to few hours ) and symptoms are facial flushing, urticaria, edema, nausea , vomiting, diarrhea as well as neurological involvement, tingling and burning sensation in the mouth. Symptoms may be more severe in patients taking certain medication that slow the breakdown of histamine by their liver, such as isoniazide and doxycycline (Taylor et al., 1989).

Table (2) showed that histamine concentrations recorded in Romano cheese were $(22.96 \pm 1.17$ and $18.35 \pm 1.12 \mathrm{mg} / 100 \mathrm{gm})$ in both low and high quality one while, low concentrations were in Kariesh cheese (14.73 \pm 0.85 and $11.26 \pm 0.61 \mathrm{mg} / 100 \mathrm{gm})$ respectively . Higher results were recorded by Dardir and Abeer (2007) specially in cheddar cheese (63.9 \pm $16.5 \mathrm{mg} / \mathrm{kg}$ ) while in kariesh cheese recorded $(8.0 \pm 2.7 \mathrm{mg} / \mathrm{kg})$. Ekbal and Amr (2010) recorded low levels of histamine in cheddar cheese $(12.98 \pm 0.81 \mathrm{mg} / 100 \mathrm{~g})$. The low level of histamine may be attributed either to its presence below the detectable level or it was catabolized by microorganisms or enzymes (Chang et al., 1985). The Egyptian Organization for Standardization "EOS" (1996) recorded the permissible level of biogenic amines in cheese was $20 \mathrm{mg} \%$ so, about $50 \%$ of Romano samples were exceeded the permissible limits.

The formation of high levels of histamine and tyramine in foods is directly correlated to the level of microorganisms, possessing the enzymes: histadine and tyrozyne decarboxylases, and also with the concentration of histidine and tyrosine free substrate. Proteolysis, which takes places during ripening of cheeses may play role in the release of free histidine and tyrosine (Fonberg and Sawilska, 1995).

Great fluctuations of amine content are reported in the same type of product. These differences depend on many variables: the quailquantitative composition of microbial microflora , the chemico- physical variables, the hygienic procedure adopted during production, and the availabilityof precursors (Suzzi and Gardini, 2003).

Cadaverine can be related to contamination of cheese with species of Enterobacteriaceae (Jooster and Northolt, 1987).

Table (3) showed lower incidence of cadaverine in all the examined samples manufactured from both raw and pasteurized milk specially Romano cheese which represented by $(6.57 \pm 0.39$ and $3.28 \pm 0.26 \mathrm{mg} / 100 \mathrm{gm})$ in low and high quality levels, respectively.

Comparing with the Egyptian Organization for Standardization "EOS" (1996) all the samples were within the permissible limit except $20 \%$ and $10 \%$ from kariesh and cheddar cheeses were non acceptable samples. These may be attributed to the unhygienic conditions in preparing and manufacturing procesesses. The obtained results were lower than that recorded by Dardir and Abeer (2007) and the obtained one by Ekbal and Amr (2010).

The diamines, putrescine and cadaverine, were found in higher concentrations in Pecorino di Fossa and Pecorino di Farindola. In particular, Mascaro et al., (2010) in Pecorino di Fossa found values of 579.60 and $1302.86 \mathrm{mg} / \mathrm{kg}$ for putrescine and cadaverine, respectively; while in samples of Pecorino di Farindola, putrescine ranged from 9.9 to $394 \mathrm{mg} / \mathrm{kg}$ and cadaverine from 26.8 to $276.1 \mathrm{mg} / \mathrm{kg}$ (Schirone et al., 2011). Tyramine was always present at high concentrations compared with the other amines of the same cheese. Among ten batches of Pecorino di Farindola (Schirone et al., 2011) tyramine resulted to be the BA present in the highest concentration in all cheeses examined, representing in six samples more than $40 \%$ of the total amines. High values of this BA have been determined also in Pecorino di Fossa, Pecorino Abruzzese and Pecorino di MigliarinoSan Rossore, particularly in the cheese core $(1300 \mathrm{mg} / \mathrm{kg})$. The relevant incidence of tyramine in cheese manufactured from raw ewes' 
milk has been reported (Roig-Saguès et al., 2002; Martuscelli et al., 2005; Pintado et al., 2008; Ladero et al., 2010).

The high level of tyramine in the Pecorino cheese could be due to the activity of thermoresistant enterococci, usual contaminants of raw milk. However, the heat resistance at more than $65^{\circ} \mathrm{C}$ of some Lactobacillus species, and in particular of $L$. paracasei, has been demonstrated (Jordan and Cogan, 1999). There is evidence that $\mathrm{LAB}$ is occasionally associated with tyramine formation, although they can also contribute to the accumulation of other BA such as putrescine. On the contrary, Enterobacteriaceae would be associated with cadaverine, putrescine, and histamine formation, mainly when a deterioration process occurs in either raw materials or end products (Marino et al., 2003).

Table (1): Statistical analytical results of tyramine levels $(\mathrm{mg} / 100 \mathrm{gm})$ in the examined samples of different cheese varieties $(\mathrm{n}=10)$.

\begin{tabular}{|c|c|c|c|c|c|c|c|c|c|c|c|}
\hline \multirow{3}{*}{ Cheese } & \multirow{3}{*}{$\begin{array}{l}\text { MRL** } \\
(\operatorname{mg} \%)\end{array}$} & \multicolumn{5}{|c|}{ Low hygienic level } & \multicolumn{5}{|c|}{ High hygienic level } \\
\hline & & \multicolumn{2}{|c|}{$\begin{array}{c}\text { Non } \\
\text { acceptable }\end{array}$} & \multirow[t]{2}{*}{ Min } & \multirow[t]{2}{*}{$\operatorname{Max}$} & \multirow[t]{2}{*}{ Mean \pm S.E } & \multicolumn{2}{|c|}{$\begin{array}{c}\text { Non } \\
\text { acceptable }\end{array}$} & \multirow[t]{2}{*}{ Min } & \multirow[t]{2}{*}{$\operatorname{Max}$} & \multirow[t]{2}{*}{ Mean \pm S.E } \\
\hline & & No & $\%$ & & & & No & $\%$ & & & \\
\hline \multirow{3}{*}{$\begin{array}{l}\text { Kariesh }^{\mathrm{A}} \\
\text { Cheddar }^{\mathrm{B}} \\
\text { Romano }^{\mathrm{B}}\end{array}$} & 20 & 5 & 50 & 9.1 & 76.3 & $29.64 \pm 1.72$ & 3 & 30 & 5.9 & 43.4 & $17.48 \pm 1.09 *$ \\
\hline & 20 & 5 & 50 & 8.5 & 59.4 & $25.37 \pm 1.49$ & 2 & 20 & 5.0 & 36.9 & $14.10 \pm 0.84$ \\
\hline & 20 & 3 & 30 & 5.2 & 39.7 & $18.51 \pm 0.02$ & 2 & 20 & 3.8 & 31.2 & $12.86 \pm 0.68$ \\
\hline \multicolumn{4}{|c|}{$\begin{array}{l}\text { A Manufactured from raw milk } \\
* \text { Significant differences }(\mathrm{P}<0.05)\end{array}$} & $\begin{array}{r}{ }^{\mathbf{B}} \mathrm{N} \\
* * \mathrm{E}\end{array}$ & $\begin{array}{l}\text { ufac } \\
\text { tian }\end{array}$ & $\begin{array}{l}\text { d from Past } \\
\text { ganization } \mathrm{fc}\end{array}$ & $\begin{array}{l}\text { rized } \\
\text { Stand }\end{array}$ & K . & $\mathrm{E}$ & (1) & \\
\hline \multicolumn{12}{|c|}{$\begin{array}{l}\text { Table (2): Statistical analytical results of histamine levels }(\mathrm{mg} / 100 \mathrm{gm}) \text { in the examined samples of different } \\
\text { cheese varieties }(\mathrm{n}=10) \text {. }\end{array}$} \\
\hline \multirow{3}{*}{ Cheese } & \multirow{3}{*}{$\begin{array}{l}\text { MRL** } \\
(\operatorname{mg} \%)\end{array}$} & \multicolumn{5}{|c|}{ Low hygienic level } & \multicolumn{5}{|c|}{ High hygienic level } \\
\hline & & \multicolumn{2}{|c|}{$\begin{array}{c}\text { Non } \\
\text { acceptable }\end{array}$} & \multirow[t]{2}{*}{ Min } & \multirow[t]{2}{*}{ Max } & \multirow[t]{2}{*}{ Mean \pm S.E } & \multicolumn{2}{|c|}{$\begin{array}{c}\text { Non } \\
\text { acceptable }\end{array}$} & \multirow[t]{2}{*}{ Min } & \multirow[t]{2}{*}{ Max } & \multirow[t]{2}{*}{ Mean \pm S.E } \\
\hline & & No & $\%$ & & & & No & $\%$ & & & \\
\hline Kariesh $^{\mathbf{A}}$ & 20 & 2 & 20 & 3.3 & 31.2 & $14.73 \pm 0.85$ & 1 & 10 & 1.7 & 24.5 & $11.26 \pm 0.61 *$ \\
\hline Cheddar $^{B}$ & 20 & 3 & 30 & 5.8 & 37.8 & $15.62 \pm 0.91$ & 2 & 20 & 3.2 & 29.9 & $13.78 \pm 0.74$ \\
\hline Romano $^{B}$ & 20 & 5 & 50 & 6.4 & 51.3 & $22.96 \pm 1.17$ & 3 & 30 & 4.6 & 40.1 & $18.35 \pm 1.12$ \\
\hline
\end{tabular}

Table (3): Statistical analytical results of cadaverine levels $(\mathrm{mg} / 100 \mathrm{gm})$ in the examined samples of different cheese varieties $(\mathrm{n}=10)$.

\begin{tabular}{|c|c|c|c|c|c|c|c|c|c|c|c|}
\hline \multirow{3}{*}{ Cheese } & \multirow{3}{*}{$\begin{array}{l}\text { MRL** } \\
\text { (mg \%) }\end{array}$} & \multicolumn{5}{|c|}{ Low hygienic level } & \multicolumn{5}{|c|}{ High hygienic level } \\
\hline & & \multicolumn{2}{|c|}{$\begin{array}{c}\text { Non } \\
\text { acceptable }\end{array}$} & \multirow[t]{2}{*}{ Min } & \multirow[t]{2}{*}{ Max } & \multirow[t]{2}{*}{ Mean \pm S.E } & \multicolumn{2}{|c|}{$\begin{array}{c}\text { Non } \\
\text { acceptable }\end{array}$} & \multirow[t]{2}{*}{ Min } & \multirow[t]{2}{*}{ Max } & \multirow[t]{2}{*}{ Mean \pm S.F } \\
\hline & & No & $\%$ & & & & No & $\%$ & & & \\
\hline Kariesh $^{\mathbf{A}}$ & 20 & 2 & 20 & 2.1 & 25.8 & $9.91 \pm 0.60$ & - & - & 1.6 & 14.3 & $5.61 \pm 0.37 *$ \\
\hline Cheddar $^{B}$ & 20 & 1 & 10 & 1.5 & 20.9 & $8.46 \pm 0.52$ & - & - & 1.0 & 12.2 & $5.04 \pm 0.33$ \\
\hline Romano $^{B}$ & 20 & - & - & 1.3 & 17.2 & $6.57 \pm 0.39$ & - & - & 1.0 & 9.8 & $3.28 \pm 0.26$ \\
\hline
\end{tabular}

Table (4): Statistical analytical results of putrescine levels $(\mathrm{mg} / 100 \mathrm{gm})$ in the examined samples of different cheese varieties $(n=10)$.

\begin{tabular}{|c|c|c|c|c|c|c|c|c|c|c|c|}
\hline \multirow{3}{*}{ Cheese } & \multirow{3}{*}{$\begin{array}{l}\text { MRL** } \\
(\mathrm{mg} \%)\end{array}$} & \multicolumn{5}{|c|}{ Low hygienic level } & \multicolumn{5}{|c|}{ High hygienic level } \\
\hline & & \multicolumn{2}{|c|}{$\begin{array}{c}\text { Non } \\
\text { acceptable }\end{array}$} & \multirow[t]{2}{*}{ Min } & \multirow[t]{2}{*}{ Max } & \multirow[t]{2}{*}{ Mean \pm S.E } & \multicolumn{2}{|c|}{$\begin{array}{c}\text { Non } \\
\text { acceptable }\end{array}$} & \multirow[t]{2}{*}{ Min } & \multirow[t]{2}{*}{ Max } & \multirow[t]{2}{*}{ Mean \pm S.E } \\
\hline & & No & $\%$ & & & & No & $\%$ & & & \\
\hline Kariesh ${ }^{A}$ & 20 & 1 & 10 & 1.6 & 22.4 & $7.81 \pm 0.47$ & - & - & 1.1 & 10.7 & $4.58 \pm 0.61^{*}$ \\
\hline Cheddar $^{B}$ & 20 & 2 & 20 & 3.1 & 27.9 & $13.40 \pm 1.02$ & 1 & 10 & 2.5 & 21.2 & $10.61 \pm 0.74$ \\
\hline Romano $^{B}$ & 20 & - & - & 1.0 & 11.5 & $4.79 \pm 0.35$ & - & - & 1.0 & 8.8 & $3.14 \pm 1.12$ \\
\hline
\end{tabular}


It is well known that BA accumulation in cheese can be influenced, firstly by the microbial quality of raw milk, the sanitation procedures adopted, the use of starter cultures, and the condition and time of the ripening process (Novella-Rodríguez et al., 2004; Pinho et al., 2004). The differences detected in BA accumulation could be attributable to the milk used, probably because of the heterogeneity of the cheese typology considered.

Table (4) reported the highest concentrations of Putrescine in Cheddar cheese than others $(13.40 \pm 1.02$ and $10.61 \pm 0.74 \mathrm{mg} / 100 \mathrm{gm})$ respectively that lower than the obtained results by Dardir and Abeer (2007).

The results emphasize the necessity of controlling the indigenous bacterial population responsible for high production of $\mathrm{BA}$ and the use of competitive adjunct cultures could be suggested. Several factors can contribute to the qualitative and quantitative profiles of BA's in Pecorino cheese such as environmental hygienic conditions, $\mathrm{pH}$, salt concentration, water activity, fat content, pasteurization of milk, decarboxylase microorganisms, starter cultures, temperature and time of ripening, storage, part of the cheese (core, edge), and the presence of cofactor (pyridoxal phosphate, availability of aminases and deaminases). In fact physico-chemical parameters seem to favor biogenic aminepositive microbiota; both of these environmental factors can easily be modulated, in order to control growth of undesirable microorganisms.

Many genera of food bacteria are responsible of this characteristic (Suzzi and Gardini, 2003). Lactobacilli are considered producer of histamine, tyramine, and putrescine, where as enterococci are considered tyramine formers and enterobacteria cadaverine and putrescine producers.

Other extrinsic factors may play an important role in the accumulation of BA in cheese, e.g., $\mathrm{pH}$, salt concentration, water activity, and redox potential (Pinho et al., 2001).

\section{Conclusions}

The production of biogenic amines in cheese is an extremely complex phenomenon, dependent of several variables, such as the presence of microorganisms, their proteolytic and decarboxylase activities, ripening time and ripening temperature.

The formation of biogenic amines in dairy products can pose a risk for consumers, especially the sensitive ones. The levels detected in cheeses vary broadly and it seems possible to manufacture most product types with low levels of amines. The most important factors in the prevention of amine formation are the good quality of milk used and the hygienic manufacturing process.

Efforts should be made to optimize technology and secure low amines levels in cheese. Susceptible individuals should be advised to consume cheese with low biogenic amine contents, as well as, more attention is necessary for regulation to set the safe levels of all biogenic amines in foods particulary cheese and dairy products.

As recommendation, the permissible level of biogenic amines stipulated by EOS should be modified to meet the more safe standard adopted by FDA and their levels can be lowered by using of good quality raw milk and maintaining hygienic standards during manufacturing and storage processes.

\section{References}

Chang, S. F.; Ayres, J. W. and Sandine, W. E. (1985): Analysis of cheese for histamine, tyramine, tryptamine ,histidine,tyrosine and tryptophane.J.Dairy Sci.,68(11):2840-6.

Dardir, H. A. and Abeer, A. Abdel-aLL (2007): Assessment of cheese quality by chromatographic analysis of biogenic amines. J. Egypt. Vet. Med. Assoc., 67 (3): 215227.

Edwards, S. T. and Sandine, W. E. (1981): Public health significance of amines in cheese. J.Dairy Sci., 64:2431.

Egyptian Organization for Standardization and Quality Control "E.O.S."(1996): Detection of poisons and control, Report.pp:1796.

Ekbal, M. A. I. and Amr, A. A. (2010): Comparison of biogenic amines levels in different processed cheese varieties with regulatory specifications .World Journal of Dairy and Food Science. , 5(2):127-133.

Feldman , D. ; Hoffman, R. and Simpson, J. (2003): The solution for data analysis and presentation graphics. $2^{\text {nd }}$ Ed., Abacus Lancripts, Inc., Barkeley, CA, U.S.A

Fonberg- Broczek, M. and Sawilska-Rautenstrauch, D. (1995): Level of histamine and tyramine in ripening cheeses. Rocz Panstw Zakl Hig. 46 (3):243-6.

Halasz, A.; Barath, A.; Simon-Sarkadi, L. and Holzapfel, W. (1994): Biogenic amines and their production by microorganisms in food. J. Food Sci., Technol. 5:42-49.

Jarisch, R. (2004): Histamine -Intoleranz Histamine und Seekrankheit .(Histamine intolerance. Histamine and motion sickness).Stuttgart, Germany: Georg Thieme Verlag.K.G. (in German).

Jooster, H. M. L. J. and Northolt, M. D. (1987): Conditions allowing the formation of biogenic amines in cheese, Neth.Milk Dairy J.41: 259-263.

Jordan, K. N. and Cogan T. M. (1999). Heat resistance of Lactobacillus spp. isolated from Cheddar cheese. Lett. Appl. Microbiol. 29: 136-140.

Jover, T. H.; Puldio, I. M.; Nogues, M. T. V.; Font, M. A. and Carou, M. C. V. (1997): Biogenic amine and polyamine contents in meat and meat products.J.Agricult.Food Chem., 45: 2098-2102. 
Ladero, V.; Martínez, N.; Martín, M. C.; Fernández, M. and Alvarez, M. A. (2010): $\mathrm{qPCR}$ for quantitative detection tyramine-producing bacteria in dairy products. Food Res. Int. 43: 289-295.

Lange, J.; Thomas, K. and Wittman, C. (2002): Comparison of capillary electrophoresis method with high performance liquid chromatography for the determination of biogenic amines in various food samples. J Chromat, 779: 229-239

Larque, E.; Sabatere-Molina, M. and Zamora, S. (2007): Biological significance of dietary polyamines. Nutrition, Jan; 23(1):87-95

Lembke, A. (1978): Histamine, a little-considered noxious substance in foodstuffs. Milchwissenschaft, 33(10):614.

Linares, D. M.; Martin, M. C.; Ladero, V.; Alvarez, M. A. and Fernandez, M. (2011): Biogenic amines in dairy products, Crit. Rev. Food Sci.Nutr. 51 (7): 691-703.

Mah, J. H.; Han, H. K. Oh.; Kim, M. G. and Hwang, H. J. (2002): Biogenic amines in Jetkoals, Korean salted and fermented fish products . Food Chemistry 79: 239-243.

Maijala, R. and Eerola, S. (2002): Biogenic Amines. Veterinary and Food Research Institute, Helsinki Finland.

Marino, M.; Maifreni, M. and Rondinini, G. (2003): Microbiological characterization of artisanal Montasio cheese: analysis of its indigenous lactic acid bacteria. FEMS Microbiol. Lett. 229: 133-140.

Martuscelli, M.; Gardini, F.; Torriani, S.; Mastrocola, D.; Serio, A.; Chaves-Lopez C.; Schirone, M. and Suzzi G. (2005): Production of biogenic amines during the ripening of Pecorino Abruzzese cheese. Int. Dairy J. 15, $571-578$

Mascaro, N.; Stocchi, R.; Ricciutelli, M.; Cammertoni, N.; Renzi, F.; Cecchini, S.; Loschi, A. R. and Rea, S. (2010): Biogenic amine content and chemical and physical features of italian formaggio di Fossa. Associazione Italiana Veterinari Igienisti 8: 49-53.

Moret, S. and Conte, L.(1996): High performance liquid chromatographic evaluation of biogenic amines in foods. J. Chromatography,729:363-369.

Novella-Rodrguiez, S.; Veciana Nogus, M. T.; Izquierdo-Pulido, M. and Vidal-Carou, M. C. (2003): Distribution of biogenic amines and polyamines in cheese , Journal of Food Science 3 pp.750-755.

Novella-Rodriguez, S.; Veciana-Nogues, M. T.; RoigSagues, A. X.; Trujillo -Mesa , A. J. and Vidal-Carou, M. C. (2004): Evaluation of biogenic amines and microbial counts throughout the ripening of goat cheeses from pasteurized and raw milk. J.Dairy Res., 71(2):245-52.

Oliveira, C. P.; Gloria, M. B. A.; Barbour, J. F. and Scanlan, R. A. (1995): Nitrate, nitrite and volatile nitrosamines in whey - containing food products . J.Agric. Food Chem. 43: 967-969.

Ordonez, A. I.; Francisco, C.; Paloma, T. and Yolanda, B. (1997): Formation of biogenic amines in food products. J Food Protection, 60(11):1371-1375.

Pinho, O.; Ferreira, I. M. P. L.; Mendes, E.; Oliveira, B. M. and Ferreira, M. (2001): Effect of temperature on evolution of free amino acid and biogenic amines content during storage of Azeitno cheese. Food Chem. 75:287-291.

Pinho, O.; Pintado, A. I. E. ; Gomes, A. M. P. ; Pintado,
M. M. E., Malcata F. X. and Ferreira, I. M. P. (2004): Interrelationships among microbiological physico-chemical, and biochemical properties of Terrincho cheese, with emphasis on biogenic amines. J. Food Prot. 67: 2779-2785. Pintado, A. I. E.; Pinho, O.; Ferreira, I. M. P. L. V. O.; Pintado, M. M. E.; Gomes A. M. P. and Malcata, F. X. (2008): Microbiological, biochemical and biogenic amine profiles of Terrincho cheese manufactured in several dairy farms. Int. Dairy J. 18: 631-640.

Polo, M. C.; Ramos, M. and Sanchez, R. (1985): Free amino acids by high performance liquid chromatography and peptides by gel electrophoresis in Mahon cheese during ripening .Food Chemistry, 16: 85-96.

Rice, S.; Eitenmiller, R. R. and Koehler, P. E. (1976): Histamine and tyramine content of meat products. J.Milk and Food Technol., 38(4):256-258.

Roig-Saguès, A. X.; Molina, A. P. and HernandezHerrero, M. M. (2002). Histamine and tyramine-forming microorganisms in Spanish traditional cheeses. Eur. Food Res. Technol. 215: 96-100.

Rodriguez, S. N.; Nogues, M. T. V.; Sagues, A. X. R.; Mesa, A. J. T. and Carou, M. C. V. (2004): Evaluation of biogenic amines and microbial counts throughout the ripening of goat cheeses from pasteurized and raw milk .J.Dairy Res.,71(2):245-252.

Schirone, M.; Tofalo, R.; Mazzone, G.; Corsetti, A. and Suzzi, G. (2011): Biogenic amine content and microbiological profile of Pecorino di Farindola cheese. Food Microbiol. 28: 128-136.

Schneller, R.; Good, P. and Jenny, M. (1997): Influence of pasteurized milk, raw milk and different ripening cultures on biogenic amines concentrations in semi-soft cheeses during ripening.Z.Lebensmunters-Forsch., A204: 265-272.

Spano, G.; Russo, P.; Lovvaud-Funel, A.; Lucas, P.; Alexandre, H.; Grandvalet, C.; Coton, E.; Coton, M.; Barnavon, L.; Bach, B.; Rattary, F.; Bunte, A.; Magni, C.; Ladero, V.; Alvarez, M.; Fernandez, M.; Lopez, P.; De Palencia, P. F.; Corbi, A.; Trip, H. and Lolkema, J. S. (2010): Biogenic amines in fermented foods .Eur. J.Clin. Nutr. Nov; 64 Suppl. 3:S95-100.

Stratton, J. E.; Hutkins, R. W. and Taylor, S. L. (1991): Biogenic amines in cheese and other fermented food : a review .J.Food Protect.54: 460-470.

Stratton, J. E.; Hutkins, R. W.; Summer, S. S. and Taylor, S. L. (1992): Histamine and histamine producing bacteria in retail Swiss and low-salt cheeses. J.Food Protect. 55: 433-439.

Suzzi, G. and Gardini, F. (2003): Biogenic amines in dry fermented sausages : a review.Int.J.Food Microbiol.,15; 88(1): 41-54.

Taylor, S. L.; Stratton, J. E. and Nordlee, J. A. (1989): Histamine poisoning (scombroid fish poisoning): an allergy - like intoxication. J. Toxicol. Clin.Toxicol. 27(4-5):225240.

Vale, S. R. and Gloria, M. B. A. (1997): Determination of biogenic amines in cheese.J.AOAC Int.80: 1006-1012.

Vinci, G. and Antonelli, M. L. (2002): Biogenic amines: quality index of freshness in red and white meat ,Food Control 13: 519-524. 